\title{
Studies of the Mixed Lymphocyte Reaction by the Virus Plaque Assay ${ }^{1}$
}

\author{
Shogo Kano, ${ }^{2}$ Barry R. Bloom, ${ }^{2}$ Donald C. Shreffler, ${ }^{3}$ Dolores Schendel, ${ }^{4}$ \\ AND FRITZ H. BACH 4 \\ 2 Department of Microbiology and Inmunology, Albert Einstein College of Medicine, Bronx, \\ New York 10461, ' Department of Human Genetics, University of Michigan Medical \\ School, Ann Arbor, Michigan 48104, and 4 Department of Medical Genetics and \\ Surgery, Imnnnobiology Research Cenler, University of Wisconsin, \\ Madison, Wisconsin 53706
}

Received July 2, 1975

\begin{abstract}
The virus plaque assay has been developed as a tool for enumerating activated lymphocytes. In previous studies using mitogens it was found that the assay detects activated $\mathrm{T}$ - but not activated B-lymphocytes. In the present studies, the mixed lymphocyte reaction was studied by the virus plaque assay as well as by incorporation of thymidine and development of cytotoxic lymphocytcs. In combinations differing at the entire major histocompatibility complex, approximately $1 \%$ of the cells were activated and treatment with anti-thy.1 serum totally abrogated the virus plaque forming cell (V-PFC) response. In studies on the A.TH-A.TL recombinants and the AQR-B10/ $6 \mathrm{R}$ recombinant strains, incompatibility at the $\mathrm{H}-2-\mathrm{K}$ or $\mathrm{H}-2-\mathrm{D}$ loci were found not to be capable of activating $\mathrm{T}$-cells to produce virus plaques. In contrast, differences in $\mathrm{I}$ or I plus $\mathrm{S}$ regions caused a marked $\mathrm{T}$-cell activation, $3-6 \%$ of the cells being $\mathrm{V}$-PFC. There was a general parallelism between thymidine incorporation and the $V$-PFC, and it was not possible to dissociate the cell types carrying out each of these functions by kinetic studies. However, preinfection of responding cells with the virus used in these studies, vesicular stomatitis virus, caused a complete abrogation of thymidine incorporation, indicating that the activation of virus is an earler stage than DNA synthesis, and that viral activation will block further cell replicaton and is probably a lytic event.
\end{abstract}

\section{INTRODUCTION}

The mixed lymphocyte and graft-versus-host reactions are unique among immunologic reactions in that a very high response is obtained with unimmunized cells, which is apparently not increased after repeated immunization. The frequency of cells responding to foreign histocompatibility antigens has been estimated to be as high as $1-3 \%(1-5)$. In addition, the mixed lymphocyte reaction (MLR) stimulates several parameters of allograft rejection; blast cell transformation and thymidine incorporation being regarded as a recognition phase and lymphocytemediated cytotoxicity serving as the effector phase.

As recombinant mouse strain combinations became available, it has been possible to test the importance of different $\mathrm{H}-2$ regions in MLR both for stimulation of the recognition function and as target determinants for cell-mediated cytolysis (6-9).

1 Supported by grants from the National Institutes of Health and The National Foundation. 
In these studies, it has been shown that I-region differences give strong MLC stimulation, whereas $K$ or $D$ region differences give very weak, if any, MI.C. stimulation. In contrast, however, $\mathrm{K}$ and $\mathrm{D}$ region differences serve as target determinants for destruction of cells bearing them by lymphocytes activated by stimulating cells differing at $I$ region plus $K$ or $D$ loci. However, target cells from strains differing solely in I region genes either are not, or only poorly killed by lymphocytes responding solely to products of this region.

A virus plaque assay has been developed for estimating the number of activated thymus-derived lymphocytes. It is based on the observation that unstimulated small lymphocytes do not support the replication of RNA viruses, whereas, antigen or mitogen stimulated lymphocytes acquire the capacity to do so (10-12). In previous studies of activation of mouse spleen cells by mitogens, it was found that concanavalin A (Con A), phytohemagglutinin (PHA), and pokeweed mitogen were highly effective at stimulating virus plaque forming cells (12). As many as 6-10\% of the spleen cells stimulated with Con A were capable of producing virus, and all of these were found to be T-cells since the response could be ablated by treatment with anti-thy. 1 serum plus complement. In contrast, while lipopolysaccharide (LPS) was effective in stimulating thymidine incorporation, there was only a very slight increase above background of virus plaque forming cells, indicating that activated B-lymphocytes are probably not measured by this assay. In these studies, MLR between strains congenic at $\mathrm{H}-2$ but differing at the $\mathrm{M}$ locus were studied. Killer cells were not seen in this system yet the virus plaque assay appeared not to detcct cells activated in this system. Consequently, the present studies were undertaken to explore in greater detail the requirements for production of $\mathrm{V}-\mathrm{PFC}$ in MLR by utilizing a variety of mouse $\mathrm{H}-2$ recombinant strains.

\section{MATERIALS AND METHODS}

Mice. All of the experiments were done with sets of inbred and congenic resistant strains of mice. The H-2 haplotypes of the strains employed and the alleles at the regions of the $\mathrm{H}-2$ complex are given in Table 1.

TABLE 1

The H-2 Haplotype and the Composition of H-2 Regions

\begin{tabular}{|c|c|c|c|c|c|c|}
\hline \multirow[t]{2}{*}{ Strain } & \multirow[t]{2}{*}{ Abbreviation } & \multirow[t]{2}{*}{ H-2 haplotype } & \multicolumn{4}{|c|}{$\mathrm{H}-2$ regions } \\
\hline & & & $\mathrm{K}$ & I & S & D \\
\hline A.AL/Sf & A.AL & $\mathrm{A} 1$ (a1) & $\mathrm{k}$ & $\mathrm{k}$ & $\mathrm{k}$ & $\mathrm{d}$ \\
\hline A.TI./Sf & A.TL & $\mathrm{t} 1 \quad(\mathrm{t} 1)$ & $\mathbf{s}$ & $\mathrm{k}$ & $\mathrm{k}$ & $\mathrm{d}$ \\
\hline A.TH/Sf & A.TH & $\mathrm{t} 2$ (th) & $\mathrm{s}$ & $\mathrm{s}$ & $\mathrm{s}$ & $\mathrm{d}$ \\
\hline A.SW/Sn & A.SW & $\mathrm{s}$ & $\mathrm{s}$ & $\mathrm{s}$ & $\mathrm{s}$ & $\mathrm{s}$ \\
\hline $\mathrm{AQR} / \mathrm{K} 1 \mathbf{j}$ & $\mathrm{AQR}$ & $y 1(y-K 1 j)$ & $\mathrm{q}$ & $\mathrm{k}$ & $\mathrm{k}$ & $\mathrm{d}$ \\
\hline B10.T (6R) & $6 \mathrm{R}$ & y2 $(y-S g)$ & $\mathrm{q}$ & $\mathrm{q}$ & $q$ & $\mathrm{~d}$ \\
\hline $\mathrm{B} 10 . \mathrm{A} / \mathrm{Sg}$ & B10.A & a & $\mathrm{k}$ & $\mathrm{k}$ & $\mathrm{d}$ & $\mathrm{d}$ \\
\hline $\mathrm{B} 10 . \mathrm{A}(2 \mathrm{R}) / \mathrm{Sg}$ & $2 \mathrm{R}$ & $h^{2} \quad(h-2 S g)$ & $\mathrm{k}$ & $\mathbf{k}$ & d & $\mathrm{b}$ \\
\hline B10.A (4R)/Sg & $4 \mathrm{R}$ & h4 (h-3Sg) & $\mathbf{k}$ & $k / b$ & $\mathrm{~b}$ & $\mathrm{~b}$ \\
\hline $\mathrm{C} 57 \mathrm{BL} / 10 \mathrm{~J}$ & B10 & b & $\mathrm{b}$ & $\mathrm{b}$ & $\mathrm{b}$ & $\mathrm{b}$ \\
\hline B10.D2/nSn & B10.D2 & d & $\mathrm{d}$ & d & d & d \\
\hline $\mathrm{C} 57 \mathrm{BL} / 6 \mathrm{~J}$ & B6 & b & $\mathrm{b}$ & b & $\mathrm{b}$ & $\mathrm{b}$ \\
\hline B6.C-H (z1) & $\mathrm{H}(\mathrm{z} 1)$ & ba & $\mathrm{b}$ ? & $\mathrm{b}$ ? & $\mathrm{b}$ & $\mathrm{b}$ \\
\hline
\end{tabular}


A.TL carries the $\mathrm{H}-2^{\mathrm{t} 1}\left(\mathrm{H}-2^{\mathrm{t} 1}\right)$ haplotype, ${ }^{5}$ derived from recombination between $\mathrm{H}-2^{\mathrm{a} 1}\left(\mathrm{H}-2^{\mathrm{a} 1}\right)$ (strain A.AL) and $\mathrm{H}-2^{\mathrm{s}}$ (strain A.SW) (14). A.TH carries the the $\mathrm{H}-2^{\mathrm{t} 2}\left(\mathrm{H}-2^{\mathrm{th}}\right)$ haplotype, derived from recombination between $\mathrm{H}-2^{\mathrm{a}}$ (strain $\mathrm{A}$ ) and $\mathrm{H}_{-2}{ }^{\mathrm{s}}$ (strain A.SW) (15). A.TL and A.TH are identical at H-2K and H-2D loci, but different at Ir-1A, Ir-1B, and Ss-S1p loci.

AQR carries the $\left.\mathrm{H}-2^{\mathrm{y} 1} \mathrm{H}-2^{y-\mathrm{K} 11}\right)$ haplotype, derived from recombination between $\mathrm{H}-2^{a}$ (strain T138) and $\mathrm{H}-2^{\mathrm{a}}$ (strain B10.A). Although $\mathrm{AQR}$ is not congenic with $\mathrm{B} 10$, it had undergone a total of four backcrossings to $\mathrm{B} 10$ before the line was established by intercrossing and thus carries a considerable portion of the B10 genome $(16)$. B10.T $(6 \mathrm{R})$ carries the $\mathrm{H}-2^{\mathrm{y} 2}\left(\mathrm{H}-2^{\mathrm{Y}-\mathrm{sg}}\right)$ haplotype derived from recombination between $H-2^{a}$ (strain $B 10 . A$ ) and $H-2^{a}$ (strain $\left.B 10 . G\right)$ (17).

$2 \mathrm{R}$ and $4 \mathrm{R}$ were derived from recombination between $\mathrm{H}-2^{\mathrm{a}}$ (strain $\mathrm{B} 10 . \mathrm{A}$ ) and $\mathrm{H}-2^{\mathrm{b}}$ (strain $\mathrm{B} 10$ ), are indistinguishable from one another at $\mathrm{H}-2 \mathrm{~K}$ and $\mathrm{H}-2 \mathrm{D}$ loci (16) and differ at Ir-1B locus and by Slp antigen. Skin graft exchanges between them are accepted for at least 40 days.

$\mathrm{H}(\mathrm{zl})$ is an $\mathrm{H}-2$ mutant, originally detected in a (C57BL/ $/ 6 \times \mathrm{BALB} / \mathrm{c}) \mathrm{F}_{1}$ hybrid and crossed onto the C57BL/6 background (18). The mutation occurred in the H-2 complex to the left of Ss-Slp locus, probably in the $\mathrm{K}$ region. Extensive inmunization failed to produce cytotoxic or hemagglutinating antisera between $\mathrm{H}(\mathrm{zl})$ and $\mathrm{B} 6 \mathrm{until}$ recently (19). Skin grafts were rejected rapidly.

Mixed lymphocyte culture. Mouse spleen cells were used as both responding and stimulating cells. Stimulating cells were treated with mitomycin $\mathrm{C}\left(25 \mu \mathrm{g} / \mathrm{ml}, 37^{\circ} \mathrm{C}\right.$ for $20 \mathrm{~min}$ ) and washed three times. Five million responding cells were cultured with $5 \times 10^{6}$ mitomycin C-treated syngeneic or allogeneic stimulating cells in $2 \mathrm{ml}$ vol of RPMI 1640 (Associated Biomedic Systems, Inc., Buffalo, N.Y.), supplemented with heat-inactivated $\left(56^{\circ} \mathrm{C}\right.$ for $30 \mathrm{~min}$ ) fetal calf serum (Reheis Chemical Co., Chicago, Ill., Lot No. H72208), $5 \mathrm{ml} / 100 \mathrm{ml}$; penicillin, 100 units $/ \mathrm{ml}$; streptomycin, $100 \mu \mathrm{g} / \mathrm{ml}$; and L-glutamine, $2 \mathrm{mM}$ (RPMI 1640, $5 \%$ FCS), in Linbro culture dishes (Linbro Chemical Co., New Haven, Conn., FB-16-24-TC, 16-nm diam), at $37^{\circ} \mathrm{C}$ in an atmosphere of $5 \% \mathrm{CO}_{2}$ in humidified air.

On the fourth day, cells from three or four replicate cultures were collected, centrifuged once, resuspended in fresh culture medium and assayed for $\left[{ }^{3} \mathrm{H}\right]$ thymidine incorporation and virus replication.

Assay of $\left[{ }^{3} H\right]$ thymidine incorporation. Two-tenths milliliter of cell suspension recovered from mixed lymphocyte cultures was transferred to microculture plate (IS-FB-960TC, Linbro Chemical Co., New Haven, Conn.) and incubated with 2 $\mu \mathrm{Ci}$ of $\left[{ }^{3} \mathrm{H}\right]$ thymidine (sp act $2.0 \mathrm{Ci} /$ mmole, New England Nuclear, Boston, Mass.) for $6 \mathrm{hr}$ at $37^{\circ} \mathrm{C}$ in $5 \% \mathrm{CO}_{2}$ in humidified air. Triplicate or quadruplicate cultures were made for each combination. The cultures were harvested onto glassfiber filters, washed with saline, precipitated with $5 \%$ TCA, and washed with methanol, by using a semiantomatic multiple sample harvester (MASH-11, Microbiological Associates. Bethesda, Md). The glass fiber filters with precipitates were placed in I.SC Minj-Vials (New England Nuclear, Boston, Mass.), dried, dissolver in $4.5 \mathrm{ml}$ of Omnifluor (New England Nuclear, Boston, Mass.) in toluene (4 $\mathrm{g} /$ liter), and assayed by li(fuid scintillation spectrophotometry.

${ }^{5}$ Proposed genetic nomenclature for the $\mathrm{H}-2$ complex and designation of $\mathrm{H}-2$ haplotypes $(6,13)$ are used in the paper (old symbols are shown in parentheses.) 
Virus plaque assay. Details of the method have been described previously (1012). After viable cell counting by trypan blue exclusion, $1 \times 10^{6}$ viable lymphocytes were transferred to $12 \times 75-\mathrm{mm}$ a Falcon plastic tube, washed once, and resuspended in $0.2 \mathrm{ml}$ of culture medium. The cells were infected with vesicular stomatitis virus (VSV) at a multiplicity of 50 and incubated at $37^{\circ} \mathrm{C}$ in $5 \% \mathrm{CO}_{2}$ in air for $2 \mathrm{hr}$ to permit virus adsorption and penetration. The excess virus was then removed by washing once, and free virus remaining was neutralized with $0.02 \mathrm{ml}$ of inactivated guinea pig anti-VSV serum by incubation for $1 \mathrm{hr}$ at $4^{\circ} \mathrm{C}$. The cells were washed three times more and resuspended in $2 \mathrm{ml}$ of Eagle's MEM with $6 \%$ fetal calf serum. A $0.2-\mathrm{ml}$ aliquot of VSV-infected cell suspensions was mixed with $1 \mathrm{ml}$ of $1 \%$ agar in MEM-6\% FCS and plated on L-cell monolayer in $60-\mathrm{mm}$ Falcon culture dishes. When this layer af agar had solidified, a second $1.5-\mathrm{ml}$ agar layer was added as a nutrient layer. Each cell sample was plated in three log dilutions, and each dilution was plated in duplicate. At the end of plating, cell counts were made in $0.2 \%$ trypan blue to determine the number of viable cells actually plated. The plates were incubated at $37^{\circ} \mathrm{C}$ in $5 \% \mathrm{CO}_{2}$ in air for 2 days, then vitally stained with neutral red solution (1:10,000 in phosphate-buffered saline), and the virus plaques were counted. The results were expressed as V-PFC (virus plaque forming cells ) $/ 10^{6}$ cells actually plated or corrected as $\mathrm{V}-\mathrm{PFC} / 10^{6}$ cells cultured.

Assay of lymphocyte cytotoxicity. P-815 mastocytoma cells (DBA/2, H-2 ${ }^{\mathrm{d}}$ ), and EL-4 lymphoma cells (C57BL/6, $\mathrm{H}-2^{\mathrm{b}}$ ) were used as target cells. They were maintained in Joklik modified MEM spinner medium with $5 \%$ fetal calf serum in stationary culture. Target cells $\left(5 \times 10^{6} \mathrm{cells} / \mathrm{ml}\right)$ were labeled with $100 \mu \mathrm{Ci}$ of $\mathrm{Na}_{2}{ }^{51} \mathrm{CrO}_{4}$ (New England Nuclear, Boston, Mass.) at $37^{\circ} \mathrm{C}$ in $5 \% \mathrm{CO}_{2}$ in air for $45 \mathrm{~min}$. After three washings they were adjusted to $1 \times 10^{6}$ viable cells $/ \mathrm{ml}$ in RPMI 1640-5\% FCS.

The cytotoxicity assay was a modification of that described by Cerottini and Brunner (20). Lymphocytes from mixed lymphocyte cultures were adjusted to a concentration of $5 \times 10^{6}$ viable cells/ml in RPMI 1640-5\% FCS. One-half milliliter of lymphocyte suspension $\left(2.5 \times 10^{6}\right)$ and $0.05 \mathrm{ml}$ of target cell suspension $\left(5 \times 10^{4}\right)$ were incubated in $12 \times 75-\mathrm{mmm}$ Falcon plastic tubes (lymphocyte:target cell ratio $=50: 1$ ) at $37^{\circ} \mathrm{C}$ in $5 \% \mathrm{CO}_{2}$ in air for $5 \mathrm{hr}$ without rocking.

At the end of the incubation period, $1 \mathrm{ml}$ of RPMI 1640-5\% FCS was added to each tube. The cells were mixed well and centrifuged. One milliliter of the supernatant fluid was aspirated and the amount of radioactivity released in the supernatant fluid was determined. Maximum ${ }^{51} \mathrm{Cr}$ release was determined by counting the amount of ${ }^{51} \mathrm{Cr}$ released into supernatant fluid by freezing and thawing $5 \times 10^{4}$ target cells three times. Spontaneous ${ }^{51} \mathrm{Cr}$ release was determined as an amount of ${ }^{5} \mathrm{Cr}$ released into supernatant fluid by incubating $5 \times 10^{4}$ target cells in culture medium alone. The results were expressed as a percentage of lysis using the following formula:

$\frac{\text { Experimental release }- \text { spontaneous release }}{\text { maximum }- \text { spontaneous release }} \times 100$.

All assays were done in triplicate.

Anti-thy-1.2 treatment. AKR anti-CBA thymocyte serum was a gift from Dr. M. Howe. Rabbit serum absorbed with EL-4 cells in the presence of EDTA was used as the source of complement (RS) (21). Anti-thy-1.2 treatment was done accord- 
ing to the method of E. A. Boyse (21). RPMI 1640 with $2 \%$ FCS was used as suspending and diluting medium. Mixtures of equal volumes of (1) anti-thy-1.2 serum $(1: 20)$; or normal mouse serum $(1: 20)$; (2) RS (1:3); and (3) lymphocytes from mixed lymphocyte culture $\left(5 \times 10^{6} / \mathrm{ml}\right)$ was incubated at $37^{\circ} \mathrm{C}$ in a water bath for $45 \mathrm{~min}$. After incubation, viable cell counts were made by adding $0.1 \mathrm{ml}$ of $0.2 \%$ trypan blue solution to $0.15 \mathrm{ml}$ of incubation mixture.

Percentage of specific kill by anti-thy-1.2 serum was cletermined as follows:

Number of viable cells with normal mouse serum -

number of viable cells with anti-Thy-1.2 serum

number of viable cells with normal mouse serum

\section{RESUI.TS}

\section{Detection of Activated Thymus-Derived Lymphocytes in the Mixed Lymphocyte Culture}

An increase in the number of cells which support the replication of an RNA virus, vesicular stomatitis virus (VSV), was found in the mixed lymphocyte culture using combinations of congenic resistant strains, B10 and B10.D2 (Table 2). The virus plaque forming cell ( $\mathrm{V}-\mathrm{PFC}$ ) response in the mitogen-activated mouse spleen cell cultures was previously shown to be predominantly, and probably exclusively, a T-cell response (12). In order to ascertain whether the virus plaque assay also detects activated T-lymphocytes in the MLC, the cells harvested from the MLC on day $4\left(5 \times 10^{6} / \mathrm{ml}\right)$ were treated with AKR anti-thy-1.2 serum $(1: 20)$ and absorbed rabbit complement $(1: 3)$. Then $1 \times 10^{6}$ cells which survived the treatment were infected with VSV for the virus plaque assay. Anti-thy-1.2 treatment lysed $49 \%$ of B10 spleen cells stimulated with B10.D2 spleen cells, and 35\% of $\mathrm{B} 10$ spleen cells cultured with syngeneic spleen cells. The $\mathrm{V}$-PFC response was expressed as $\mathrm{V}$-PFC $/ 10^{\circ}$ cells treated. Anti-thy -1.2 treatment reduced $\mathrm{V}$-PFC in stimulated cultures by $93 \%$ to the unstimulated background level (Table 2). Similar reductions were observed in $\left[{ }^{3} \mathrm{H}\right]$ thymidine incorporation. These results confirm

TABLE 2

Effect of Anti-Thy-1.2 Serum on V-PFC in MLCa

\begin{tabular}{|c|c|c|c|c|}
\hline Culture & $\begin{array}{c}\text { Cell recovery } \\
\text { from culture } \\
(\%)\end{array}$ & 'Treatment & $\begin{array}{c}\text { Specific kill } \\
\text { by anti- } \\
\text { thy-1.2 } \\
(\%)\end{array}$ & $\begin{array}{l}\mathrm{V}-\mathrm{PFC} / 10^{\circ} \\
\text { cells treated }\end{array}$ \\
\hline $\mathrm{B} 10+\mathrm{B} 10_{\mathrm{m}}$ & 20 & $\begin{array}{l}\text { NuS }+\mathrm{C} \\
\text { Anti-thy-1.2 }+\mathrm{C}\end{array}$ & 35 & $\begin{array}{l}789 \\
784\end{array}$ \\
\hline $\mathrm{B} 10+\mathrm{B} 10 . \mathrm{D} 2 \mathrm{~m}$ & 42 & $\begin{array}{l}\mathrm{N} \mathrm{MS}+\mathrm{C} \\
\text { Anti-thy-1.2 + C }\end{array}$ & 49 & $\begin{array}{r}9248 \\
6.30\end{array}$ \\
\hline
\end{tabular}

${ }^{a}$ B10 spleen cells, $5 \times 10^{6}$, were cultured with $5 \times 10^{6}$ mitomycin C-treated B10 or B10.D2 spleen cells in RPMI $1640+5 \%$ FCS for 4 days. Viable spleen cells, $10 \times 10^{6}$, from pooled cultures were treated with anti-thy-1.2 or normal mouse serum (1:60, final dilution) and absorbed rabbit complement $\left(1: 9\right.$, final dilution). Surviving lymphocytes, $1 \times 10^{6}$, were then infected with VSV for the virus plaque assay. VPA was done in duplicate. The results were corrected as V-PFC/ $10^{6}$ cells treated with anti-thy-1.2 serum. 
TABLE 3

Relative Importance of Different H-2 Regions for V-PFC Response ${ }^{a}$

\begin{tabular}{|c|c|c|c|c|}
\hline $\begin{array}{l}\text { Responding } \\
\text { cells }\end{array}$ & $\begin{array}{l}\text { Stimulating } \\
\text { cells }\end{array}$ & $\begin{array}{l}\mathrm{H}-2 \text { region } \\
\text { difference }\end{array}$ & 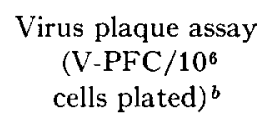 & $\begin{array}{l}\left.{ }^{[3} \mathrm{H}\right] \text { thymidine } \\
\text { incorporation } \\
\text { (cpm/culture) }\end{array}$ \\
\hline A.TH & A.TH & None & $1,355 \pm 292$ & $6,281 \pm 62$ \\
\hline A. TH & A.TL & $\mathrm{I}, \mathrm{S}$ & $22,064 \pm 3,287$ & $56,726 \pm 598$ \\
\hline A.TH & A.SW & $\mathrm{D}$ & $1,254 \pm 109$ & $4,866 \pm \quad 78$ \\
\hline A.TH & A.AL & $\mathrm{K}, \mathrm{I}, \mathrm{S}$ & $13,398 \pm 2,349$ & $46,675 \pm 1,144$ \\
\hline A.TL & A.TL & None & $2,212 \pm 146$ & $6,939 \pm 142$ \\
\hline A.TL & A.TH & I, S & $28,640 \pm 1,646$ & $32,787 \pm 1,542$ \\
\hline A.TL & A.AL & $\mathrm{K}$ & $1,793 \pm 182$ & $7,119 \pm 319$ \\
\hline A.TL & A.SW & $\mathrm{I}, \mathrm{S}, \mathrm{D}$ & $11,787 \pm 227$ & $19,773 \pm 1,212$ \\
\hline
\end{tabular}

a Spleen cells, $5 \times 10^{8}$, were cultured with $5 \times 10^{6}$ mitomycin C-treated stimulating spleen cells in $2 \mathrm{ml}$ of RPMI 1640 with $5 \%$ FCS for 4 days. Viable cells, $1 \times 10^{6}$, from pooled cultures were infected with VSV for the virus plaque assay. Two-tenths-milliliter aliquots of culture were incubated with $2 \mu \mathrm{Ci}$ of $\left[{ }^{3} \mathrm{H}\right]$ thymidine for $6 \mathrm{hr}$.

${ }^{b}$ Mean $\pm \mathrm{SE}(n=3)$.

$c$ Mean $\pm \operatorname{SE}(n=4)$.

that the MLC reaction is predominantly T-cell response and activated T-lymphocytes can be enumerated by the virus plaque assay.

\section{Relative Importance of Different Regions of the H-2 Complex for $V-P F C$ Response}

MLC and the cell-mediated lympholysis (CML) have been regarded as in vitro correlates of the recognition phase and effector phase of the allograft reactions, respectively. Recent studies using rccombinant strains within $\mathrm{H}-2$ complex enhanced our knowledge about relative importance of different regions of the $\mathrm{H}-2$ complex for MLC stimulation $(7,8)$ and generation of the cytotoxic lymphocytes $(9)$.

As a means to clarify whether the virus plaques assay measures all the activated T-lymphocytes or a subpopulation of the activated lymphocytes such as effector cells, the relative importance of different regions of the $\mathrm{H}-2$ complex for the $\mathrm{V}-\mathrm{PFC}$ response was studied using sets of recombinant strain combinations.

A representative result of the most informative strain combinations is shown in Table 3. A.TH and A.TL strains, which are identical at $\mathrm{H}-2 \mathrm{~K}$ and $\mathrm{H}-2 \mathrm{D}$ loci, but differ in $\mathrm{I}$ and $\mathrm{S}$ regions, stimulate strong $\mathrm{V}-\mathrm{PFC}$ response reciprocally. On the other hand, A.TH spleen cells cultured with A.SW spleen cells (H-2D locus difference), or A.TL spleen cells cultured with A.AL spleen cells (H-2K locus difference) did not give significant $\mathrm{V}-\mathrm{PFC}$ response above their control syngeneic cultures. Addition of $K$ or $D$ region differences to the $I$ and $S$ region difference did not increase the $\mathrm{V}-\mathrm{PFC}$ response (Table 3 ).

The importance of the region between $\mathrm{H}-2 \mathrm{~K}$ and $\mathrm{H}-2 \mathrm{D}$ for $\mathrm{V}-\mathrm{PFC}$ response was also demonstrated in another recombinant strain. AQR spleen cells stimulated with $6 \mathrm{R}$ cells, which are identical at $\mathrm{H}-2 \mathrm{~K}$ and $\mathrm{H}-2 \mathrm{D}$ loci but different in $\mathrm{I}$ and $\mathrm{S}$ regions, also gave strong $\mathrm{V}-\mathrm{PFC}$ responses. The same $\mathrm{AQR}$ spleen cells cultured with B10.A cells which are different at $\mathrm{H}-2 \mathrm{~K}$ locus gave no significant $\mathrm{V}-\mathrm{PFC}$ response (Table 4 ). 
TABLE 4

Relative Importance of Different H-2 Regions for V-PFC Responsea

\begin{tabular}{|c|c|c|c|c|}
\hline $\begin{array}{l}\text { Responding } \\
\text { cells }\end{array}$ & $\begin{array}{l}\text { Stimulating } \\
\text { cells }\end{array}$ & $\begin{array}{l}\text { H-2 region } \\
\text { difference }\end{array}$ & 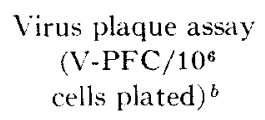 & $\begin{array}{l}{\left[{ }^{3} \mathrm{H}\right] \text { thymidine }} \\
\text { incorporation } \\
\text { (cpm/culture })^{c}\end{array}$ \\
\hline$A Q R$ & $A Q R$ & None & $1,302 \pm 145$ & $2,610 \pm 165$ \\
\hline $\mathrm{AQR}$ & $6 \mathrm{R}$ & $\mathrm{I}, \mathrm{S}$ & $10,797 \pm 2,251$ & $9,443 \pm 916$ \\
\hline $\mathrm{AQR}$ & $\mathrm{B} 10 . \mathrm{A}$ & $\mathrm{K}$ & $1,359 \pm 146$ & $3,835 \pm 57$ \\
\hline
\end{tabular}

Strains $4 \mathrm{R}$ and $2 \mathrm{R}$ derived from recombinations of $\mathrm{H}-2^{\mathrm{a}}$ and $\mathrm{H}-2^{\mathrm{b}}$ chromosome and are identical at $\mathrm{H}-2 \mathrm{~K}, \mathrm{H}-2 \mathrm{D}$, and I-A loci. $4 \mathrm{R}$ spleen cells stimulated with $2 \mathrm{R}$ cells showed a significant but relatively weak $\mathrm{V}$-PFC response. Addition of $\mathrm{D}$ region incompatibility ( $4 \mathrm{R}$ stimulated with $\mathrm{B} 10 . \mathrm{A}$ ) increased the magnitude of the $\mathrm{V}-\mathrm{PFC}$ response. The $\mathrm{K}$ and $\mathrm{I}-\mathrm{A}$ region incompatible combination ( $4 \mathrm{R}$ stimulated with $B 10)$ gave highcr $V-P F C$ response than $I-B, S$, and $D$ region incompatible combination (4R stimulated with B10.A) (Table 5).

$\mathrm{H}(\mathrm{zl})$ is congenic with B6, the only known difference being a mutation in the $\mathrm{H}-2$ complex, to the left of Ss-Slp locus, presumably in $\mathrm{K}$. The exact location and extent of the mutation is not clear. $\mathrm{B} 6$ and $\mathrm{H}(\mathrm{zl})$ stimulated reciprocally to give a marked $V$-PFC response (Table 6).

\section{Kinetics of the V-PFC Response in MLC}

As another approach to clarify the relationship of the $\mathrm{V}$-PFC response with cell proliferation and development of cytotoxic lymphocytes, their kinetics were compared in the mixed lymphocyte culture. B10 spleen cells cultured with B10.D2 spleen cells or B10 cells were harvested each day and assayed for virus replication, $\left[{ }^{3} \mathrm{H}\right]$ thymidine incorporation and cytotoxicity against $\mathrm{P}-815$ mastocytoma ( $\mathrm{H}-2^{\mathrm{d}}$ ) target cells (Fig. 1). The increment of $\mathrm{V}$-PFC or counts per minute in allogeneic culture above syngeneic culture increased apparently exponentially till day 5 and then declined sharply. The ratio of counts per minute in allogeneic cultures to counts per minute in syngeneic culture reached its peak on day 4 and declined thereafter mainly because of increased background $\left[{ }^{3} \mathrm{H}\right]$ thymidine incorporation in

TABLE 5

Relative Importance of Different H-2 Regions for V-PFC Response:"

\begin{tabular}{|c|c|c|c|c|}
\hline $\begin{array}{l}\text { Responding } \\
\text { cells }\end{array}$ & $\begin{array}{l}\text { Stimulating } \\
\text { cells }\end{array}$ & $\begin{array}{l}\text { H-2 region } \\
\text { difference }\end{array}$ & $\begin{array}{c}\text { Virus plaque assay } \\
\left(\mathrm{V}-\mathrm{PFC} / 10^{6}\right. \\
\text { cells plated })^{b}\end{array}$ & $\begin{array}{l}{\left[{ }^{3} \mathrm{H}\right] \text { thymidine }} \\
\text { incorporation } \\
(\mathrm{cpm} / \mathrm{culture})^{c}\end{array}$ \\
\hline $4 \mathrm{R}$ & $4 \mathrm{~K}$ & None & $1,791 \pm$ & $3,319 \pm$ \\
\hline $4 \mathrm{R}$ & $2 \mathrm{R}$ & $\mathrm{I}-\mathrm{B}, \mathrm{S}$ & $6,175 \pm 328$ & $10,655 \pm 464$ \\
\hline $4 \mathrm{R}$ & B10.A & $\mathrm{I}-\mathrm{B}, \mathrm{S}, \mathrm{D}$ & $12,937 \pm 1,910$ & $22,400 \pm 517$ \\
\hline $4 R$ & $\mathrm{~B} 10$ & $\mathrm{~K}, \mathrm{I}-\mathrm{A}$ & $39,584 \pm 7,179$ & $38,377 \pm 1,283$ \\
\hline
\end{tabular}

$a, b, c$ See foot notes $a, b, c$, Table 3 . 
TABLE 6

Relative Importance of Different H-2 Regions for V-PFC Response ${ }^{a}$

\begin{tabular}{lllrr}
\hline $\begin{array}{c}\text { Responding } \\
\text { cells }\end{array}$ & $\begin{array}{c}\text { Stimulating } \\
\text { cells }\end{array}$ & \multicolumn{1}{c}{$\begin{array}{c}\text { H-2 region } \\
\text { differencc }\end{array}$} & $\begin{array}{r}\text { Virus plaque assay } \\
\text { (V-PFC } / 10^{6} \\
\text { cells plated })^{b}\end{array}$ & $\begin{array}{r}\text { [ } \\
\text { incorporation } \\
\text { (cpm/culture) }\end{array}$ \\
\hline B6 & B6 & None & $2,194 \pm 337$ & $3,998 \pm 121$ \\
B6 & H(z1) & Mutation in K or I & $20,745 \pm 2,497$ & $44,124 \pm 1,409$ \\
B6 & B10.D2 & K, I, S, D non-H-2 & $74,465 \pm 4,259$ & $43,496 \pm 1,730$ \\
H(z1) & H(z1) & None & $13,781 \pm 4,526$ & $20,501 \pm 1,363$ \\
H(z1) & B6 & Mutation in K or I & $66,707 \pm 6,859$ & $44,669 \pm 2,120$ \\
H(z1) & B10.D2 & K, I, S, D non-H-2 & $70,501 \pm 11,982$ & $52,948 \pm 3,400$ \\
\hline
\end{tabular}

$a, b, c$ See footnotes $a, b, c$, Table 3 .

syngeneic culture. Lymphocyte cytotoxicity was very weak on days 2 and 3, rose on day 4 , reached its peak on day 5 and remained high. Changes in culture conditions (data not shown) had a significant effect on the kinetics, and the results indicated that the kinetics of all three reactions were similar and not a useful parameter for distinguishing subpopulations.

\section{Effect of Preinfection with VSV on $\left[{ }^{3} \mathrm{H}\right]$ Thymidine Incorporation in the Mixed} Lymphocyte Culture

In order to distinguish whether the virus replicating cells and the thymidine incorporating cells are the same cells or distinct cell populations, the effect of preinfection of spleen cells with VSV on $\left[{ }^{3} \mathrm{H}\right]$ thymidine incorporation was investigated. The basis of this experiment is that, if virus replication occurs in the same cells as $\left[{ }^{3} \mathrm{H}\right]$ thymidine incorporating cells, virus replication would be likely to

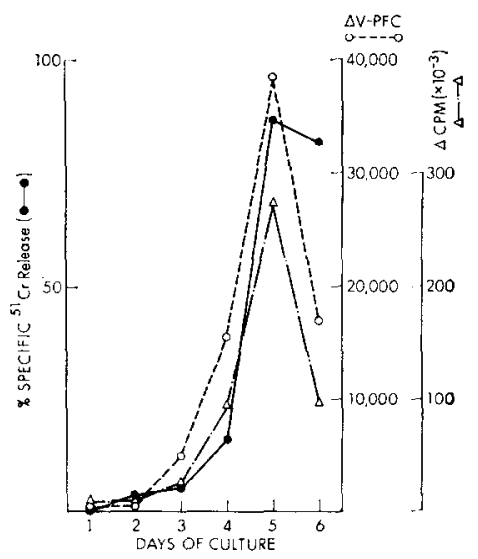

FIG. 1. B10 spleen cells $\left(5 \times 10^{\circ}\right)$ were cultured with $5 \times 10^{6}$ mitomycin C-treated B10.D2 or $\mathrm{B} 10$ spleen cells. V-PFC $/ 10^{\circ}$ viable cells plated (means of triplicate assays) : (O- - $\mathrm{O}$ ), Increase in $\mathrm{V}-\mathrm{PFC}$ in $\mathrm{B} 10+\mathrm{B} 10 . \mathrm{D} 2_{\mathrm{m}}$ culture above $\mathrm{B} 10+\mathrm{B} 10_{\mathrm{m}}$ culture. $(\triangle-\triangle)$, Increase in $\left[{ }^{3} \mathrm{H}\right]$ thymidinc incorporation in $\mathrm{B} 10+\mathrm{B} 10 . \mathrm{D} 2$ in culture above $\mathrm{B} 10+\mathrm{B} 10_{\mathrm{m}}$ culture. (๑- ) , Increase in ${ }^{51} \mathrm{Cr}$ release from $\mathrm{P}-815$ mastocytoma cells by cells from $\mathrm{B} 10+$ $\mathrm{B} 10 . \mathrm{D} 2_{\mathrm{m}}$ culture above $\mathrm{B} 10+\mathrm{B} 10_{\mathrm{m}}$ culture. 
occur earlier after activation than DNA synthesis and virus infection may abolish $\left[{ }^{3} \mathrm{H}\right]$ thymidine incorporation. If $\left[{ }^{3} \mathrm{H}\right]$ thymidine incorporating cells are a distinct cell population independent of the virus replicating cells, virus infection will not affect $\left[{ }^{3} \mathrm{H}\right]$ thymidine incorporation in the mixed lymphocyte culture. B10 spleen cells were infected with VSV at a multiplicity of infection of 50 for $2 \mathrm{hr}$ at $37^{\circ} \mathrm{C}$ and then washed three times to remove free virus. Infected $\mathrm{B} 10$ spleen cells and uninfected control B10 spleen cells were cultured with mitomycin C treated B10.D2 or B10 spleen cells for 4 days and assayed for $\left[{ }^{3} \mathrm{H}\right]$ thymidine incorporation.

The results of one such experiment is shown in Table 7 . Preinfection with VSV reduced $\left[{ }^{3} \mathrm{H}\right]$ thymidine incorporation both in allogeneic combination and in syngeneic combination. Although the allogeneic cultures of preinfected spleen cells usually gave higher $\left[{ }^{3} \mathrm{H}\right]$ thymidine incorporation than syngeneic cultures, the reduction in response by preinfection in terms of $\Delta \mathrm{cpm}$ per culture was greater than $98 \%$.

\section{DISCUSSION}

When the virus plaque assay (VPA) was applied to MLR involving differences across the entire major histocompatibility complex, a striking increase in virus plaque forming cells was observed, indicating approximately $1 \%$ of the cells were activated (Table 2). Treatment of the responding cells with anti-thy.1 serum and complement totally abrogated the response demonstrating that the cells being detected by the virus plaque assay are indeed T-cells.

Studies on two recombinant strain combinations indicated that stimulation of the $\mathrm{V}$-PFC response by $\mathrm{H}-2^{\mathrm{k}}$ or $\mathrm{H}-2^{\mathrm{d}}$ locus incompatibility was insignificant (Tables 3 and 4 ). However, I region or $\mathrm{I}+\mathrm{S}$ region differences led to marked stimulation (3-6\% V-PFC). Addition of $\mathrm{H}-2^{\mathrm{k}}$ or $\mathrm{H}-2^{\mathrm{d}}$ locus incompatibilities to $\mathrm{I}$ and $\mathrm{S}$ region differences did not increase the number of responding cells.

Studies on the $4 \mathrm{R}$ and $2 \mathrm{R}$ recombinants indicated that significant stimulation was obtained in strains differing by I-A and I-B subregions, the former being essentially four times more cffective than the latter. In this combination, there was some additive effect when a $D$ end incompatibility was present together with differences at I-B and $\mathrm{S}$. While this result might be suggestive of additional weak

TABI.E 7

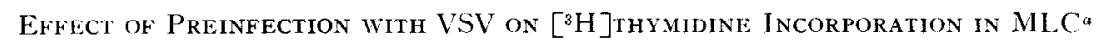

\begin{tabular}{|c|c|c|c|c|}
\hline $\begin{array}{l}\text { Preinfection } \\
\text { with VSV }\end{array}$ & Culture & $\begin{array}{c}\text { Counts per minute } \\
\text { yer culture }\end{array}$ & & \\
\hline$(-)$ & $\mathrm{B} 10 . \mathrm{D} 2+\mathrm{B} 10 . \mathrm{D} 2_{\mathrm{n}}$ & $4,515 \pm 147$ & & \\
\hline() & $\mathrm{B} 10 . \mathrm{D} 2+\mathrm{B} 10_{\mathrm{u}}$ & $20,177 \pm 22.3$ & $\Delta=15,662$ & S.I. $=4.5$ \\
\hline $\begin{array}{l}(+) \\
(+)\end{array}$ & $\begin{array}{l}\mathrm{B} 10 . \mathrm{D} 2+\mathrm{B} 10 . \mathrm{D} 2 \mathrm{~m} \\
\mathrm{~B} 10 . \mathrm{D} 2+\mathrm{B} 10_{\mathrm{m}}\end{array}$ & $\begin{array}{r}56 \pm 15 \\
170 \pm 39\end{array}$ & $\Delta=$ & S.I. $=3.0$ \\
\hline
\end{tabular}

\footnotetext{
a B10.D2 spleen cells were incubated with VSV at m.o.i. of 100 at $37^{\circ} \mathrm{C}$ for $2 \mathrm{hr}$, then washed three times. Infected spleen cells $\left(5 \times 10^{6}\right)$ were cultured with $5 \times 10^{6}$ mitomycin $\mathrm{C}$-treated B10.D2 or B10 spleen cells for 5 days. Two-tenth-milliliter aliquots or cultures were labeled with $2 \mu \mathrm{Ci}$ of $\left[{ }^{3} \mathrm{H}\right]$ thymidine for $6 \mathrm{hr}$.

b Mean $\pm \mathrm{SE}(n=4)$.
} 
MLC determinants coded for by a region between SS and $D$, because additive effects of $D$ or $K$ end determinants in two other systems were not seen, the result could as well be an idiosyncrasy of the $2 \mathrm{R}-4 \mathrm{R}$ combination.

One anomalous strain combination was studied, namely the $\mathrm{B} 6 / \mathrm{Hzl}$ combination, which is believed to be identical to the $\mathrm{I}, \mathrm{S}$, and $\mathrm{D}$ regions, but to differ from the parent $\mathrm{B} 6$ strain by virtue of a mutation in the $\mathrm{K}$ region. Recently a serological difference has been detected between these strains (19). In the present studies, a strong activation of T-cells was detected by the VPA, which is consistent with the in vivo finding that grafts between these strains are mutually rejected. It thus appears that in terms of genetic determinants governing lymphocyte activation, there were no significant differences between those stimulating thymidine incorporation and those generating $\mathrm{V}$-PFC.

In order to try to distinguish the functional differences between activated lymphocytes measured by thymidine incorporation, cytotoxicity, and the virus plaque assay, a series of kinetic experiments were carried ant on the development of each of the functional parameters. Under conditions which optimized the yield of V-PFC and cytotoxic lymphocytes, the peak of all activities was found on day 5 of culture (Fig. 1), although different culture conditions were found to have a significant effect on the peak responses of the various parameters. We are forced to conclude that it is very difficult to differentiate V-PFC either from thymidine incorporating cells or cytotoxic lymphocytes by means of kinetic studies. One additional difficulty in these studies on mouse lymphocyte cultures has been the variable and low percentage of recovery of viable cells per culture, and it is not known whether there is any selectivity in cell loss for cells carrying out different functions under the different culture conditions.

A comparison of the results with the virus plaque assay with other parameters used to study mixed lymphocyte cultures is given in Table 8 . There appears to be a relative parallelism between the $\mathrm{V}$-PFC response, thymidine incorporation, and graft rejection in vivo. The major discrepancy derives from the experiences in a number of laboratories which have been unable to demonstrate cell-mediated cytotoxicity across determinants coded for solely by the I region. Unfortunately, it is difficult to interpret this observation, because Ia determinants coded for by the I region and detected serologically are usually not detected, or found in only low amounts, on mouse tumor cells and PHA activated blasts, the most common targets for cell-mediated cytolysis. There is some indication that since Ia is expressed in grcater amounts on B-lymphocytes, killing across I region differences can be

TABLE 8

Comparison of V-PFC Response with Mixed Lymphocyte Reaction, Cell-Mediated Lympholysis and Graft Rejection

\begin{tabular}{|c|c|c|c|c|}
\hline $\begin{array}{c}\text { Strain } \\
\text { combination }\end{array}$ & $\begin{array}{l}\mathrm{V} \text {-PFC } \\
\text { response }\end{array}$ & $\begin{array}{l}\text { Mixed lympho- } \\
\text { cyte reaction }\end{array}$ & $\begin{array}{c}\text { Cell mediated } \\
\text { lympholysis }\end{array}$ & $\begin{array}{c}\text { Graft } \\
\text { rejection }\end{array}$ \\
\hline A.TL-A.TH & Strong & Strong & Negative & Strong \\
\hline$A Q R-6 R$ & Strong & Strong & Negative & Strong \\
\hline $4 \mathrm{R}-2 \mathrm{R}$ & Moderate to weak & Moderate & Negative & Negative \\
\hline $\mathrm{B} 6-\mathrm{H}(\mathrm{z} 1)$ & Strong & Strong & Strong & Strong \\
\hline
\end{tabular}


letected on LPS-stimulated blasts (22) and in preliminary experiments in this Jaboratory, a tumor cell expressing serologically detected Ta determinants conld bo killed by cells generated in an MLR between A.TH and A.TL. Obviously, this point remains an important one to be clarified.

Perhaps the most unexpected finding in these studies was that infection by vesicular stomatitis virus was capable of abolishing lymphocyte activation in the MI.R. In the usual protocol, lymphocytes are activated by MLR, antigen, or mitogen, and then 4 or 5 days later infected with virus and plated for V-PFC. In the experiments described in Table 7 , resting lymphocytes were infected before being stinulated in an MLR, and the V-PFC and thymidine incorporation were measured. Under these conditions in which V-PFC are generated, there was an almost total ablation of thymidine incorporation, and in preliminary studies in generation of killer lymphocytes. It is suggested from these experiments, together with previous experiments using mitotic inlibitors, that lymphocyte activation for replication of virus is an early event, and precerles DNA syuthesis. These data are consistent with the results on synchronized human lymphoblastoid lines indicating that virus replication occurs maximally during $G_{1}$ of the cell cycle (25). Secondly, since VSV is a lytic virus, activation of preinfected cells to produce virus most likely leats to destruction of the activated cells, and thus provicles a potential strategy for eliminating histocompatibility antigen-reactive cells. Preliminary experiments carried out with I)r. M. Nowakowski, T. Romano, and J. Thorbecke $(23,24)$ indicate that preinfection of allogeneic spleen cells can abrogate their ability to generate graftversus-host responses upon transfer to immunologically compromised recipicnts.

\section{REFERENCES}

1. Simons, M. H., and Fowler, R., Nature (London) 209, 588, 1966.

2. Simonsen, M., Cold Spring Harbor Symp. Quant. Biol. 32, 517, 1967.

3. Wilson, D. B., Howard, J. C., and Nowel1, P. C., Transplant. Rev. 12, 3, 1972.

4. Wilson, D. B., Blyth, J. L., and Nowell, P. C., J. Exp. Med. 128, 1157, 1968.

5. Bach, F. H., Graupner, K., Dan, E., and Klosterman, H., Proc. Nat. Acad. Sci. US. 62 , $374,1969$.

6. Shreffler, D. C., and David, C. S., Adqan. Immunol. 18, $125,1974$.

7. Bach, F. H., Widner, M. B., Bach, M. L., and Klcin, J., J. Exp. Mcd. 136, 1430, 1972.

8. Meo, T., Vives, J., Miggiano, V., and Shreffler, D. C., Transplant. Proc. 5, 377, 1973.

9. Alter, B. J., Schendel, D. J., Bach, M. L., Bach, F. H., Klein, J., and Stimpfling, J. H., I. Fxp. Med. 137, 1303, 1973.

10. Bloom, B. R., Jimenez, L., and Marcus, P. I., J. Exp. Med. 132, 16, 1971.

11. Jimenez, L., and Bloom, B. R., In "In vitro Methods in Cell Mediated Immunity" (B. R. Bloom and P. R. Glade, Eds.), pp. 553. Academic Press, New York and London, 1971.

12. Kano, S., Bloom, B. R., and Howe, M. L., Proc. Nat. Acad. Sci. USA 70, 2299, 1973.

13. Klein, J., Demant, P., Festenstein, F., McDevitt, H. O., Shreffler, D. C., Snell, G. D., and Stimpfling, J. H., Immunogenetics 1, 184, 1974.

14. David, C. S., and Shreffler, D. C., Tissue Antigens 2, 241, 1972.

15. Shreffer, D. C., and David, C. S., Tissue Antigens 2, 232, 1972.

16. Klein, J., Klein, D., and Shreffler, D. C., Transplantation 10, 309, 1970.

17. Stimpfling, J. H., and Reichert, A. E., Transpiant. Proc. 2, 39, 1970.

18. Bailey, D. W., Snell, G. D., and Cherry, M., In "Immunogenetics of the H-2 system" (A. Lengerova and M. Vojtiskova, Eds.), p. 155. S. Karger, Basel.

19. KIcin, J., Hauptfeld, M., IIauptfeld, V., J. Exp. Med. 140, 1127, 1974.

20. Cerottini, J. C., and Brunner, K. T., In "In vitro Methods in Cell Mediated Immunity" (B. R. Bloom and P. R. Glade, Eds.), p. 369. Academic Press, New York, 1971. 
21. Boyse, E. A., Hubbard, L., Stockert, E., and Lamm, M. E., Transplantation 10, 446, 1970. 22. David, C. S., Shreffler, D. C., and Frelinger, J. A., Proc. Nat. Acad. Sci. USA 70, 2509, 1973.

23. Nowakowski, M., Bloom, B. R., Romano, T., and Thorbecke, J., Fed. Proc. 34, 1027, 1975.

24. Romano, T. J., Bloom, B. R., and Thorbecke, J. T., Fed. Proc. 34, 1027, 1975.

25. Bloom, B. R., Nowakowski, M., and Kano, S. In "Mechanisms of Virus Diseases" W. S. Robinson, and F. C. Fox, Eds.), pp. 25-40. ICN-UCLA Symposium. W. A. Benjamin, Menlo Park, Calif., 1975. 